\title{
INVENTORY AND TOURISM OPPORTUNITIES IN SEKUPANG - BATAM DISTRICT
}

\author{
Toni Ari Wibowo, Yudy Sunantri \\ Universitas Internasional Batam, \\ Jl.Gajah mada Sei Ladi, Batam 29442 \\ Program Studi S-1 Pariwisata \\ Email: toniariwibowo1975@gmail.com
}

\begin{abstract}
Batam in developing tourism through the activities of the types of tourism that exist inevery places of Batam, one of which is located in Sekupang District. Sekupang District with 7 existing urban villages, has tourism potential but not yet maximally in the process of inventory of tourism potential which can be a chance of one of the superior products of tourism as well as increase the splendor of Batam tourism. Opportunities and potential of tourism can be seen through the following attractions (attractiveness), accesable (system achieved), amenities (facilities), ancillary (tourism institutions). Opportunities and potentials that can be made in the development of tourism Sekupang District and make Sekupang district can contribute in Batam tourism through the potential of existing tourism.
\end{abstract}

Key Words: tourism indentification, tourism opportunity, community based tourism 
Page 892-898. ISBN: 978-602-6 988-75-1

Web Jurnal Online: jurnal.unmuhjember.ac.id

By: Toni Ari Wibowo, Yudy Sunantri

Inventory And Tourism Opportunities In Sekupang - Batam District

\section{INTRODUCTION}

Batam Island is an island in the Riau Islands Province which has a strategic geographical location with Singapore and Malaysia and Batam advanced in the world of tourism, this can be proven that Batam is the third door after Bali and Jakarta in terms of the number of tourist visits domestic and foreign. By seeing a variety of potentials that are very attractive to tourists, Batam plans tourism by completing various kinds of supporting facilities both in terms of infrastructure such as roads as accessibility to tourism objects and one area that has tourism potential is Sekupang District. Sekupang District has 7 villages including Tanjung Riau, Tiban Indah, Patam Lestari, Tiban Baru, Tiban Lama, Sungai Harapan and Tanjung Pinggir (skpd.batamkota.go.id). An area said to be a tourism destination must have tourist attractions so that it can be interesting to visit. Tourist attractions can be in the form of art, culture, nature, historical relics, sports or objects that are natural or have received human intervention. According to Soekadijo in Soeroso (2006), that a tourist attraction or tourist attraction is an embryo / initial capital to determine the policy of a tourist destination (DTW) and tourism can emerge because it starts with an attractive tourist attraction.

Sekupang District has a variety of tourism potentials that have not been properly inventoried as tourism potentials and can make tourism opportunities in Sekupang District. Sekupang District that must be considered in tourism offerings. The aspects are: 1 Attraction, where tourist destinations attract tourists should have a good attraction intended so that the tourist system and foreign countries can easily achieve the destination to the tourist attractions. 2. Accessable (system is achieved), 3 Facilities (Facilities), the third condition this has indeed become one of the requirements of a Tourist Destination Area (DTW) where tourists can feel at home staying longer in the Area.4 The existence of a Tourism Institution (Ancillary). Tourists will be more frequent visit and look for DTW (Tourist Destination Areas) if in that area tourists can feel security, (Protection of Tourism) and are protected both by reporting and submitting a criticism and suggestion regarding their existence as visitors / people traveling.

The formulation of the problem in research includes 3 things namely forms-what forms of tourism are in Sekupang subdistrict which are spread in 7 (seven) kelurahans, then what is the social, economic, and cultural profile of the people in 7 (seven) Kelurahans in Sekupang Subdistrict and how are the tourism opportunities in Sekupang Subdistrict to support City tourism Batam. Through the bidspect that refers to 4 A and 1 $\mathrm{C}$, which consists of attraction, accessibility (system is achieved), amenities (facilities), ancillary (tourism institutions) and community involvement (community involvement), this research is very interesting because the results of the study can be made as a recommendation for the tourism potential of Sekupang District to support the more vibrant tourism activities of Batam City. This research activity covers the social, economic and cultural profile of the community in 7 (seven) villages in Sekupang Subdistrict, as well as observing and interviewing to obtain inventory data and tourism opportunities in Sekupang District which will serve as tourism potential 
Page 892-898. ISBN: 978-602-6 988-75-1

Web Jurnal Online: jurnal.unmuhjember.ac.id

By: Toni Ari Wibowo, Yudy Sunantri

Inventory And Tourism Opportunities In Sekupang - Batam District

\section{LITERATURE REVIEW}

Tourist attractions can be in the form of art, culture, nature, historical relics, sports or objects that are natural or have received human intervention. According to Soekadijo in Soeroso (2006), that a tourist attraction or tourist attraction is an embryo / initial capital to determine the policy of a tourist destination (DTW) and tourism can emerge because it starts with an attractive tourist attraction. On technological developments and tourism science can be created and engineered according to the dynamics of changing demands periodically. So tourism should always conduct an assessment of the strengths (weaknesses), weaknesses (weaknesses), knowing the opportunities (opportunities) and obstacles or threats (threats). The tourists can feel directly and indirectly the tourist attractions seen and felt while visiting the tourist destination, the tourist destination can only try to satisfy tourists both in the primary tourist destination (primary destinantion) or additional tourist destinations or secondary destinations that can be referred to as stopover destination.

According to Medlik 1980 in Ariyanto 2005, there are four aspects (4A) that must be considered in tourism offerings. The aspects are: 1. Attraction, where the tourist destination in attracting tourists should have both natural and community and cultural attractions. 2. Accessable (system is achieved), this intended so that the tourist system and foreign countries can easily achieve the destination to the tourist attractions 3 . Facilities (Facilities), the third condition this has indeed become one of the requirements of a Tourist Destination Area (DTW) where tourists can feel at home staying longer in the Area. 4. The existence of a Tourism Institution (Ancillary).

Tourists will more often visit and look for DTW (Tourist Destination Areas) if in that area tourists can feel security, (Protection of Tourism) and are protected both by reporting and submitting a criticism and suggestion regarding their existence as visitors / people traveling.

According to UNESCO in collaboration with the University of Indonesia (2009) that the tourism industry is formed from 7 elements, namely: 1) Tourism information, 2) Travel Bureau, 3) Transportation, 4) Accessibility, 5.) Tourist Destinations, 6) Tourist Attractions, 7) Supporting elements such as tourism education and marketing. Infrastructure and natural and cultural resources are important requirements for the success of tourism. Likewise with public goodwill and hospitality of residents in tourist destinations Changing trends in the world of tourism:

1. Travel while learning and adventure tours are increasing in popularity.

2. Organizing small-scale tours increasingly in demand.

3. Number of tourists visiting must be limited to the level that can be tolerated by the resource being promoted.

4. Remote and inclined areas closed is actually seen as a safe tourist spot.

5. Tourists want to see different cultures, see local attractions, buy

6. local production goods, meet with local residents and attend local events. 
Page 892-898. ISBN: 978-602-6 988-75-1

Web Jurnal Online: jurnal.unmuhjember.ac.id

By: Toni Ari Wibowo, Yudy Sunantri Inventory And Tourism Opportunities In Sekupang - Batam District

\section{RESEARCH METHODS}

Inventory and tourism opportunities in Sekupang Subdistrict are carried out in 7 (seven) villages, including Tanjung Riau Village, Tiban Indah Village, Patam Lestari Village, Tiban Baru Village, Tiban Lama Village, Sungai Harapan Village and Tanjung Pinggir Village Inventory and tourism opportunities in Sekupang District through observation activities, interviews with community leaders, 7 (seven) village chiefs, district heads to get a clear picture of the tourism potential so that an inventory of tourism potential can be made in the Sekupang District.

Data obtained from a variety of data collection techniques on tourism inventories in Sekupang District will be analyzed by covering attractions, accessibility (systems achieved), amenities (facilities), ancillary (tourism institutions) and will also be analyzed using SWOT in the form of qualitative descriptive that can help in analyzing tourism opportunities obtained from both primary and secondary inventory data and SWOT analysis is expected to provide direction and scenarios in tourism development both on a micro to macro scale in Sekupang District as shown in figure 1 of the research model below

this:

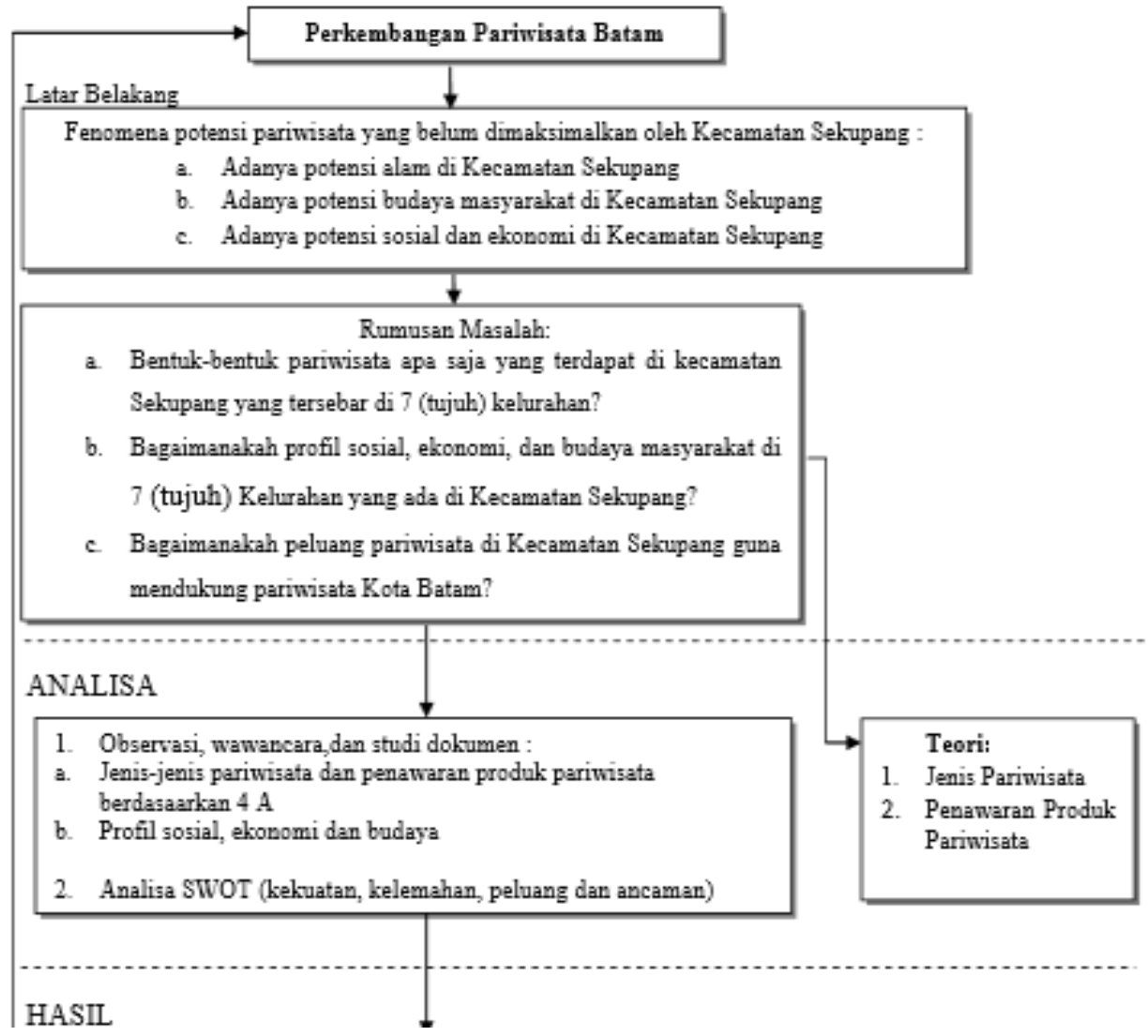


Law Number 53 Year 1999, the status of the Batam Municipality was upgraded to be Batam City which is Autonomous and Subdistrict divided into 8 (eight) district one of which is Sekupang District. As is Regional Regulation (PERDA) Batam City No. 2 of 2005, the District area divided into sub-districts Sekupang and Batu Aji District. Previous Sekupang District consists of 8 (eight) villages, after divided into 7 (seven) Districts which consists of: 1). Tanjung Village Riau, 2). Tiban Baru Village, 3). Tiban Lama Village, 4). To village of Tiban Beautiful, 5). Patam Lestari Village, 6). Sungai Harapan sub-district, 7). Kelurahan Tanjung Pinggir.

\section{RW RT in Sekupang}

\begin{tabular}{ccc}
\hline Kelurahan & $\sum \mathrm{RW}$ & $\sum \mathrm{RT}$ \\
\hline Tanjung Riau & 18 & 66 \\
Tiban Baru & 19 & 81 \\
Tiban Lama & 15 & 59 \\
Tiban Indah & 12 & 52 \\
Patam Lestari & 14 & 83 \\
Sungai Harapan & 12 & 56 \\
Tanjung Pinggir & 5 & 17 \\
\hline
\end{tabular}

\section{RESULT}

\section{Tourism Potential in the District Sekupang}

1. Marina Tourism Region The marina area has a concept is ideal as a tourism area which provides hotel facilities, tourist facilities such as beaches, agro guava fruit tour, agro Guava honey tour, animal husbandry area animals, the port of the bay of Senimba Marina also the marina entertainment area.

2. Entertainment Area Marina Marina entertainment area is one of the entertainment area a very famous and crowded night in 2004 to 2008, where in Marina entertainment area a lot equipped with bar facilities, karaoke, venue massage as well as non-star hotel complete the required facilities traveler.

3. Marina Beach, Marina Beach is one tourist attraction in the form of the beach, where in the marina beach area it can found various facilities consists of children's playground, views to Senimba bay ferry terminal, shipyard industry pemdangan and also eye forest $\mathrm{k}$ ucing a very good view so every day saturday holiday and many family weeks which for a vacation.

4. Marina Road Race Sircuit, Marina road race circuit have the length of the entire trajectory is 900 meters while the length of the straight track is 400 meters and has entered the national event in November 2017 for the event nationality nal to go car. 
Page 892-898. ISBN: 978-602-6 988-75-1

Web Jurnal Online: jurnal.unmuhjember.ac.id

By: Toni Ari Wibowo, Yudy Sunantri

Inventory And Tourism Opportunities In Sekupang - Batam District

Marina road race sircuit has collaborated with the bureau travel in Batam, this is proven a group of tourists from Best Batam travel that brings tourists to see the conditions Marina road race circuit.

5. Guava Tourism Agro Tourism is one of the pioneers of tourism enough agro in Sekupang sub-district successful and can be made as an example for other regions to be make as an agrotourism area. Agro-tourism has garden facilities guava is quite spacious equipped pendopo facilities for tourists who want to relax in the garden too useful as an educational tour for Kindergarten children who want to see how is the process of planting seeds guavas as well as how the process picking guava.

6. Dangas Beach is one fairly new tourist attraction in Sekupang subdistrict located at patam Lestari. Dangas Beach has sufficient beach length nice with sloping sand but still a little dirty due to spills oil from the ship existing large ships around the Dangas beach The Thousand Stairs was once a wilderness, so at the initiative of some local communities try open access to be visited so that now a tourist attraction ladder one thousand can be visited by tourists. Thousand stairs tourist area has very nice view, where from the tourist area Stairs A thousand can see the beauty Batam city views, beautiful Singapore, and a view ship-large ships around the tourist attraction The Thousand Stairs.

7. KTM resort is a powerhouse tourist attraction in the District Sekupang which is very famous and crowded on visit by tourists domestic and foreign countries. Where, KTM Resort has one attraction that is not contained in Other Batam Island areas namely the statue of Goddess Kwan Im with 26 meters high which is the place worship for Buddhists Other than that KTM Resort also provides accommodation for tourists who want to stay overnight equipped with restaurants, swimming pool and other resort facilities so that when staying tourists no need to bother looking for facilities other supporters.

\section{CONCLUSION}

That the community in the District Sekupang with 7 (seven) discharge That is an administrative territory government, that Kelurahan Tanjung Riau has a chance pretty much as a tourist attraction District tourism supporters Sekupang.

Tourism in Sekupang District have opportunities that can be developed into a tourist attraction as a supporter of the tourism program Batam City with a variety of to unikan which is owned in several which is in administration Sekupang district.

Tourist attraction KTM Resort and Beach Marina has a chance tourism is better compared to object tour Guava agrotourism marina, Dangas beach tourist attraction, Marina road race, tourist attraction Stairs A Thousand and Tanjung Pinggir Beach. 


\section{REFERENCES}

Arsyadha, Gita Alfa,2002, Identifikasi Potensi Wisata Kepulauan karimun

Jawa Sebagai Pemasukan Penentuan Prioritas Komponen Pendukung Pengembangan pariwisata, Jurusan Perencanaan Wilayah dan Kota. Fakultas Teknik,

Universitas Diponegoro, Semarang

Dinas Pariwisata Kota Batam.2012, Jumlah kunjungan wisatawan ke Kota Batam

Tahun 2012

Djam'an Satori dan Aan Komariah, 2011. Metodologi Pene litian Kualitatif, Bandung: Alfabeta

Inskeep dalam Suprapto, Aris. 2005" Analisis penawaran dan permintaa

Medlik dalam Ariyanto, 2005. Ekonomi Pariwisata, Jakarta: pada

http://www.gocities.com/ ariyantoeks79/ home.htm

.Nana S. Sukmadinata, 2009.Metode Penelitian Pendidikan, Bandung: PT.

Remaja Rosdakarya Nandi, Jurnal GEA” Jurusan Pendidikan Geografi Vol. 8, No.1, April 2008

Peraturan daerah Kota Batam (Perda Kota Batam) No 2 tahun 2004 tentang rencana

tata ruang wilayah kota Batam tahun 2004

Soekadijo, dalam Suroso. 2006 "Reinventing obyek wisata kota Semarang sebagai daya tarik tujuan wisatawan asing, Thesis, Program pasca sarjana Magister Lingkungan dan

Perkoteaan, Universitas katholik Soegijapranata, Semarang

Sugiyono,2009. Metode Penelitian Bisnis.Bandung:CV Alfabeta

United Nation Educational, Scientific and Cultural Organization (UNESCO) dan

Program Vokasi Universitas Indonesia bekerjasama dengan Departemen Kebudayaan dan Pariwisata Republik Indonesia ,2009, 